\title{
Urban Stream Restoration Projects: Do Project Phase, Distance, and Type Affect Nearby Property Sale Prices? ๘
}

\author{
Maya Jarrad Postbaccalaureate fellow, Department of Economics, Reed College, Portland, Oregon \\ Noelwah R. Netusil Professor, Department of Economics, Reed College, Portland, Oregon \\ Klaus Moeltner Professor, Department of Agricultural and Applied Economics, Virginia Tech, \\ Blacksburg, Virginia
}

Anita T. Morzillo Assistant professor, Department of Natural Resources and the Environment, University of Connecticut, Storrs, Connecticut

J. Alan Yeakley Professor, Department of Geography and Environmental Systems, University of Maryland Baltimore County, Baltimore, Maryland

\begin{abstract}
Between 1990 and 2014, more than 200 restoration projects were implemented in the Johnson Creek Watershed, Oregon, to mitigate storm water runoff, restore floodplains, remove invasive plants, restore wetlands, and improve fish and wildlife habitat. We use a repeat-sales model to investigate if restoration projects have an effect on the sale price of nearby single-family residential properties, and if estimated effects vary by project phase, distance, and type. Properties in closest proximity to storm water, floodplain, and revegetation projects experience a positive effect during different project phases. Estimated effects for wetland projects are negative for 9 of the 12 distance/project phase variables. (JEL Q24, Q51)
\end{abstract}

\section{Introduction}

Urban stream restoration projects, which focus on riparian areas, wetlands, stream channels, and steep hillsides where stream headwaters are located, are undertaken to increase urban ecosystem resilience and enhance urban natural resources. Stream restoration can reduce flooding and property damage, enhance fish and wildlife habitat, improve water quality, and provide recreation sites (Hughes et al. 2014). By increasing the amount of vegetation

Land Economics • August 2018 • 94 (3): 368-385 ISSN 0023-7639; E-ISSN 1543-8325

(C) 2018 by the Board of Regents of the

University of Wisconsin System in urban areas, many stream restoration projects can also improve air quality, increase carbon sequestration, and reduce urban heat island effects. These projects are often part of a broader watershed-wide strategy to use green infrastructure to reduce storm water runoff in urbanizing areas (USEPA 2013, 2014).

Substantial investments-more than \$1 billion per year-have been made in recent decades to restore streams in the United States (Bernhardt 2005). Other countries, such as China (Che et al. 2012), Australia (Polyakov et al. 2017), New Zealand, Sweden, the United Kingdom, Ecuador (Smith et al. 2016), and the Netherlands (Van Alphen 2016), are also engaging in efforts to restore urban streams. The intended effects of these projects include the mitigation of storm water runoff and flooding, maintenance of water quality, minimization of erosion, and maintenance of aquatic food webs (Pander and Geist 2013; Palmer, Filoso, and Fanelli 2014; Yeakley et al. 2016).

Despite these worldwide initiatives, few studies have estimated the effect of urban stream restoration projects on property sale prices (Kaza and BenDor 2013; Streiner and Loomis 1995; Polyakov et al. 2017). Yet, an extensive literature exists using stated preference approaches (Bergstrom and Loomis 2017; Collins, Rosenberger, and Fletcher 2005; Holmes et al. 2004; Johnston et al. 2002; Kenney et al. 2012; Loomis et al. 2000; Lupi, Kaplowitz, and Hoehn 2002; Mueller et al. 2013; Schultz et al. 2012). While revealed preference studies provide insight about use values, stated preference studies can quantify nonuse values while

7 Appendix materials are freely available at http://le.uwpress.org and via the links in the electronic version of this article. 
providing insight into public attitudes about restoration projects (Johnston et al. 2002; Lupi, Kaplowitz, and Hoehn 2002; Schultz et al. 2012). Studies have found that the benefits from restoration projects can be quite large even if only some benefits are quantified (Collins, Rosenberger, and Fletcher 2005; Mueller et al. 2013) and that project benefits may exceed the costs (Holmes et al. 2004; Kenney et al. 2012; Loomis et al. 2000).

Early work by Streiner and Loomis (1995) estimates increases in property sale prices of $3 \%$ to $13 \%$ from urban stream restoration projects in three California counties, but more recent work finds mixed results. Kaza and BenDor (2013) investigate the effect of naturally occurring aquatic systems, and aquatic systems restored as part of a state-sponsored mitigation program, in the Raleigh-DurhamChapel Hill area of North Carolina using a matching model approach. The authors find that natural aquatic systems increase property sale prices up to $0.75 \mathrm{mi}$ away. Properties located up to $0.25 \mathrm{mi}$ from restored sites, however, are estimated to have lower sale prices, while properties 0.5 to $0.75 \mathrm{mi}$ away have higher sale prices.

The effect of a restoration project's age on property sale prices is estimated in Polyakov et al.'s (2017) analysis of a $23 \mathrm{~km}^{2}$ urban drain restoration project in Perth, Western Australia. Their first modeling approach interacts a time trend variable with a binary variable that captures whether a property is within $200 \mathrm{~m}$ of the project. A second modeling approach categorizes properties into four different time periods, including a preproject period. The authors conclude that being within $200 \mathrm{~m}$ of a restoration project has a statistically negative effect on property sale prices at the start of the restoration project. This initial negative effect is overcome in four to five years and then becomes economically and significantly positive after seven to eight years.

We build on the existing literature in three ways. First, we expand the number of restoration project types by categorizing projects based on their primary project goal: storm water runoff mitigation, floodplain restoration, removal of invasive plants and revegetation, fish and wildlife habitat improvement, or wetland restoration. Second, we use three buffers
(0 to $0.25 \mathrm{~km}, 0.25$ to $0.5 \mathrm{~km}$, and $0.5 \mathrm{~km}$ to $1 \mathrm{~km}$ ) to estimate if distance from a restoration project has an effect on a property's sale price by buffer. Finally, because a restoration project's age may influence a property's sale price, our third contribution is to classify restoration projects into four project phases to account for aesthetic and functional changes over time (Naiman 2013; Weisberg, Mortenson, and Dilts 2013).

\section{Study Area}

The study area is located in the Portland, Oregon, metropolitan area in the Pacific Northwest. As of July 1, 2016, the Portland metropolitan area was the twenty-fifth largest metropolitan area in the United States with population growth between 2010 and 2016 of $8.9 \% .^{1}$ The area has a robust housing market, with the Portland, Oregon, house price index increasing by $312 \%$ between 1988 and 2014 compared to the U.S. national price index of $143 \%$; $^{2}$ recent annual housing price increases in the Portland metropolitan area have been among the highest in the nation (Njus 2017).

The study area encompasses a $5 \mathrm{~km}$ buffer around Johnson Creek's main stem and tributaries (Figures 1 and 2), which is approximately $400 \mathrm{~km}^{2}\left(154 \mathrm{mi}^{2}\right)$. The study area includes parts of eight cities, the largest of which is Portland, and unincorporated parts of two counties, Multnomah and Clackamas. The Portland metropolitan area is frequently ranked as one of the most sustainable areas in the United States (Prakash et al. 2017) and widely studied because of its innovative land use planning with a focus on "smart growth" (Ozawa 2004).

A large portion of the study area $(83 \%)$ is under the jurisdiction of Metro, a regional

\footnotetext{
${ }^{1}$ See the U.S. Census Bureau, "American FactFinder," available at https://factfinder.census.gov/faces/tableservices/ jsf/pages/productview.xhtml?src=bkmk (accessed November 4, 2017).

${ }^{2}$ See S\&P Dow Jones Indices LLC, "S\&P/Case-Shiller U.S. National Home Price Index (CSUSHPINSA)," retrieved from FRED, Federal Reserve Bank of St. Louis, available at https:// fred.stlouisfed.org/series/CSUSHPINSA?utm_source=series page\&utm_medium=related_content\&utm_term=related_ resources\&utm_campaign=categories\#0 (accessed November 4, 2017).
} 
Figure 1

Johnson Creek Watershed Boundary

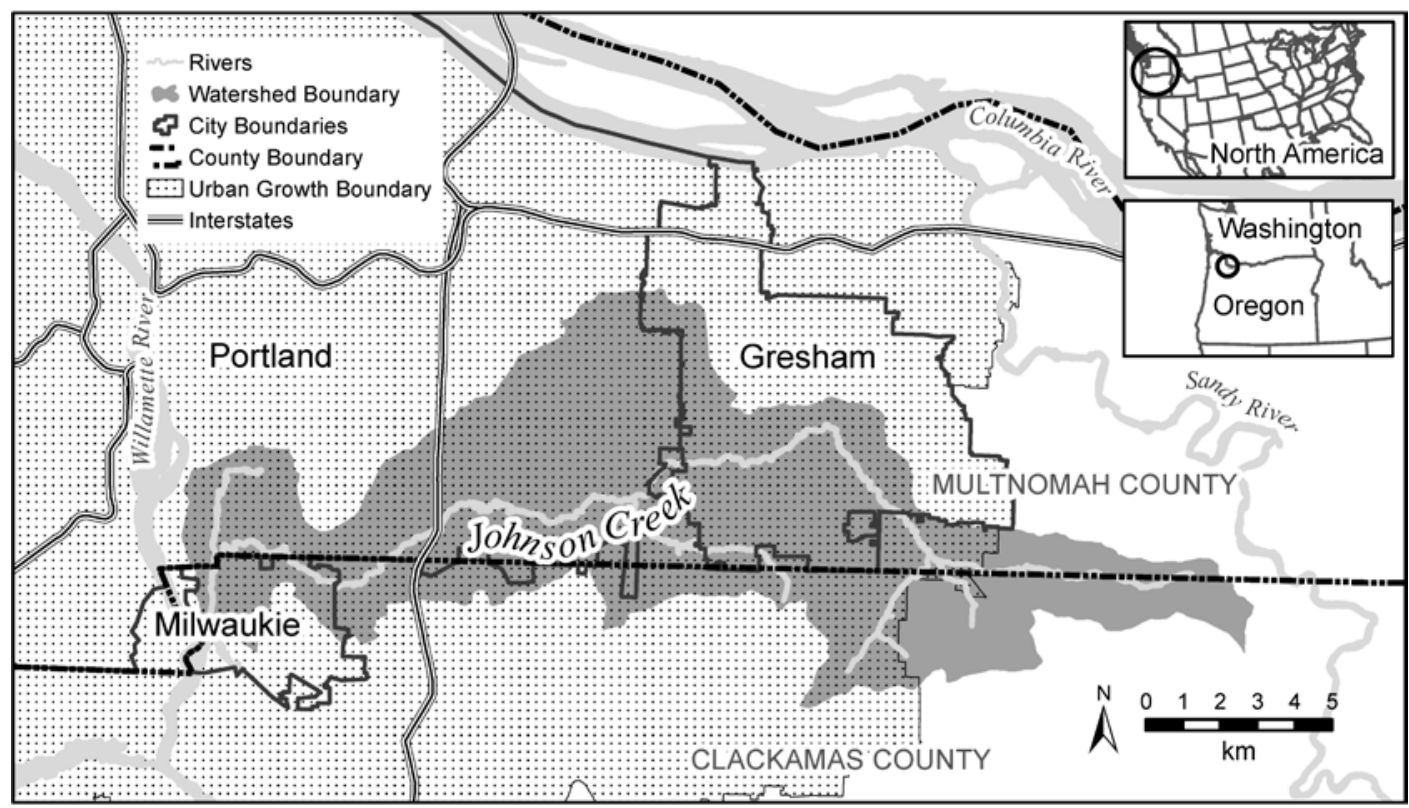

government that has jurisdiction over the Portland metropolitan area's urban growth boundary (UGB). By Oregon law, each city and metropolitan area must have a UGB to control where development occurs (Kline et al. 2014). The Portland metropolitan area's UGB was first created in 1979 and encompassed $920 \mathrm{~km}^{2}(227,472 \mathrm{ac})$ (Metro Data Resource Center 2014). The UGB has been expanded 32 times, with the largest expansion in 2002, when $72 \mathrm{~km}^{2}(17,759 \mathrm{ac})$ in the Damascus area was brought inside the UGB (Metro Data Resource Center 2015).

Johnson Creek flows $42 \mathrm{~km}$ (26 mi) from volcanic hills in the Cascade foothills westward to the Willamette River, passing through agricultural, rural and suburban residential, industrial, and urban lands (Sonoda, Yeakley, and Walker 2001). Much of the residential land in the watershed lies in a historical floodplain carved by scouring and deposits from the Missoula floods that were caused by breaches in melting glacial dams (Williams, Lee, and Snyder 2010). Consequently, flooding on residential, agricultural, and industrial lands has been a concern for many years. In the early 1930s the Works Progress Administration (WPA), with a goal of reducing flooding, deepened, rock-lined, and straightened 24 $\mathrm{km}(15 \mathrm{mi})$ of the creek in the lower basin, but these projects were not effective. Today, the volume and timing of runoff in this section of the basin is likely affected by the physical changes made by the WPA and increases in impermeable surfaces across the watershed (Williams, Lee, and Snyder 2010; U.S. Geological Survey 2011). Restoration efforts have been motivated by a number of factors including an interest in avoiding public (e.g., road repairs) and private costs (e.g., structural house damage) from flood events (Johnson Creek Watershed Council 2003; Yeakley and Hughes 2014), enhancing fish and wildlife habitat, and improving water quality.

The primary stream flow sources to Johnson Creek are precipitation runoff and groundwater discharge. In the upper basin, Johnson Creek now receives storm water faster due to agricultural drains and runoff from impermeable ditches and roads. The volume that reaches the creek has increased, and the time frame it arrives in has shortened, resulting in 
Figure 2

Restoration Projects and Property Sales

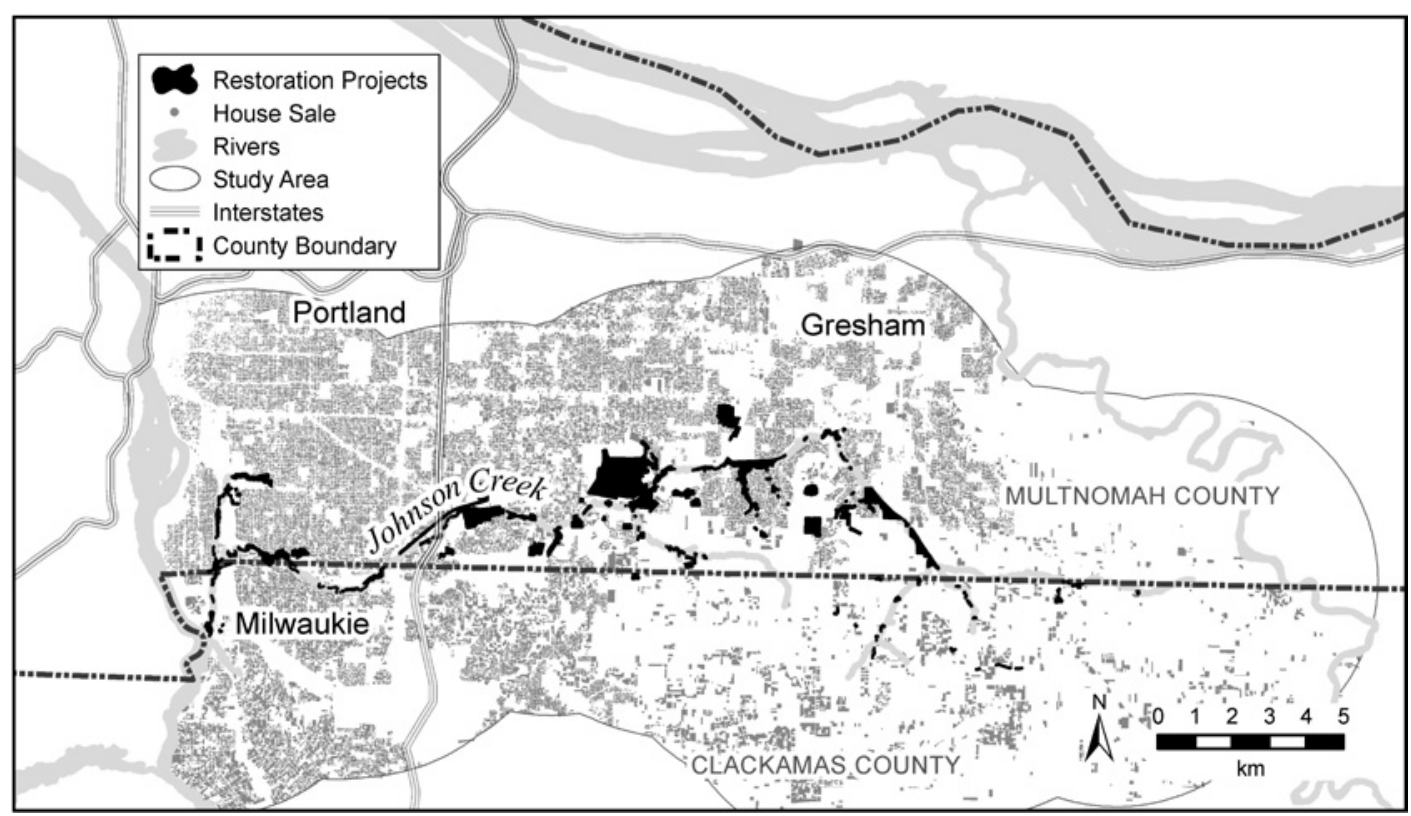

37 out-of-bank flood events between 1941 and 2006, 28 of which resulted in property damage (FEMA 2006). Floods, which occurred on average every other year until a major restoration project was completed in 2012, are shallow but cover a large area (Portland Bureau of Environmental Services 2016). Floodplain restoration projects have reduced the expected frequency of localized flooding (Ahilan et al. 2018), but flood events are still expected to occur, on average, about every six years. ${ }^{3}$

Johnson Creek has a number of species including steelhead (Oncorhynchus mykiss), Chinook salmon (O. tshawytscha), and coho salmon $(O$. kisutch) that are listed as threatened under the federal Endangered Species Act (Van Dyke and Storch 2009; NOAA Fisheries West Coast Region 2012). Salmon require a minimum flow, cool temperatures, suitable breeding and resting grounds, and

\footnotetext{
${ }^{3}$ Phone interview (September 8, 2016) with Marie Walkiewicz, Eastside Watersheds Team, Bureau of Environmental Services, Portland, Oregon, regarding BES land acquisitions in Johnson Creek.
}

water quality that meets certain standards (Maas-Hebner, Hughes, and Schreck 2014), which has motivated some restoration projects. Water quality in Johnson Creek is rated as "very poor," though improving, based on Oregon Department of Environmental Quality standards for the total maximum daily load of pollutants such as fecal coliform, thermal loading, total phosphorous and nitrate nitrogen, and dissolved oxygen levels (Merrick and Hubler 2013).

Two voter-approved bond measures in 1995 and 2006 raised $\$ 363.0$ million that was used to purchase 5,260 ha of land $(13,000 \mathrm{ac})$ including $145 \mathrm{~km}$ (90 mi) of river and stream banks and habitat for salmon and other species (Metro 2014, 2016). Since 1996, Portland's Bureau of Environmental Services has restored about 58 ha (144 ac) within Portland's portion of the watershed. ${ }^{4}$

\footnotetext{
${ }^{4}$ Phone interview (September 8, 2016) with Marie Walkiewicz, Eastside Watersheds Team, Bureau of Environmental Services, Portland, Oregon, regarding BES land acquisitions in Johnson Creek.
} 
The Springwater Corridor Trail, a public multiuse path built from 1991 to 2005 that roughly follows Johnson Creek for approximately $34 \mathrm{~km}(21 \mathrm{mi})$, allows the public to observe the creek and many of the restoration projects included in our study area (Portland Parks and Recreation 2014). Outreach efforts by government agencies and the Johnson Creek Watershed Council, which manage almost $92 \%$ of the restoration projects in our study, include direct mailings to affected property owners, community events, outreach to neighborhood organizations, coverage in local media outlets, and project websites. Portlandmaps.com, an online property records database maintained by the city of Portland, includes information about the history, program (including information about restoration efforts), location, size, and amenities of nearby parks. ${ }^{5}$ Signage posted at some restoration sites provide information about the project and contact information for the agency responsible for site management.

\section{Data}

\section{Housing Data}

Housing sales data were compiled from two sources. First, sales from 1988 to 2011 were obtained from DataQuick, a private firm that collects data from county assessors. ${ }^{6} \mathrm{Sec}-$ ond, sales from 2012 to 2014 were obtained directly from the Multnomah and Clackamas County Assessor's Offices. ${ }^{7}$

Property sales data were cleaned to include only single-family residences with at least one valid sale between 1988 and 2014. Sales missing a property ID, sale price, year of house construction, address, or sale date were dropped, because those observations were missing data needed for the analysis and because close inspection often revealed errors in other parts of the record. Properties that

\footnotetext{
${ }^{5}$ See www.portlandmaps.com.

${ }^{6}$ DataQuick has been acquired by CoreLogic (www. corelogic.com/solutions/configurable-real-estate-datareports.aspx).

${ }^{7}$ See Clackamas County Assessor website (www. clackamas.us/at/) and Multnomah County Assessor website (https://multco.us/assessment-taxation).
}

had a permitted structural improvement such as a renovation or addition were dropped for all sales concurrent and after the year of improvement, because a house's structural attributes are assumed to not change over time in a repeat-sales model (Palmquist 1982).

Properties classified as partial interest sales, refinances, timeshares, purchases by organizations or companies, distress sales, or quitclaims were dropped because they were not arm's-length transactions. Transfers of property marked as vacant or commercial were also dropped, retaining residentially zoned lots. Similar to Muehlenbachs, Spiller, and Timmins's (2015) data, observations with the lowest $1 \%$ of sale prices were dropped, since these extremely small values likely do not represent arm's-length transactions. Sales of more than $\$ 1.5$ million were individually verified using Portlandmaps.com and edited or deleted if incorrect. Some properties transacted multiple times in a year, so for these observations a single record was generated based on the average sale price for all transactions of the property in the same calendar year. ${ }^{8}$

The data set includes 128,580 sales records for 72,814 unique single-family properties. A total of 37,353 properties transacted once, so those observations are valid sales but unusable because the repeat-sales model uses the change in property sale prices between transactions as the dependent variable. Transaction pairs were formed between sales of the same property based on the number of times a property transacts. The final data set includes 35,461 unique properties that sold two to eight times, forming 55,766 transaction pairs; a table with detailed property transaction information is available in the Appendix.

Table 1 includes summary statistics for the transaction pairs used in our analysis. The mean home age increased by 8.7 years between the first and second transaction and the mean transaction price increased by $\$ 61,007$

\footnotetext{
${ }^{8}$ Multiple sales in the same year pose two issues. The first is that if two sales from the same year are paired for analysis, the change in time between sales is zero as the unit of measure for time is one year. Case et al. (2006) avoided this problem by not pairing sales consecutively. Cohen et al. (2016) systematically kept the first sale per year per property, but this may introduce bias if sale prices are depressed during the winter.
} 
Table 1

Property Characteristics of Transaction Pairs

\begin{tabular}{lrrrr}
\hline Variable & \multicolumn{1}{c}{ Mean } & Std. Dev. & Min. & Max. \\
\hline Transaction year (first transaction) & 1996.9 & 5.8 & 1988 & 2013 \\
Transaction year (second transaction) & 2003.5 & 6.1 & 1989 & 2014 \\
Home age (first transaction, years) & 46.2 & 29.4 & 1 & 138 \\
Home age (second transaction, years) & 52.8 & 29.3 & 2 & 143 \\
Price (first transaction, 2014 dollars) & 193,092 & 108,229 & 20,622 & $1,986,377$ \\
Price (second transaction, 2014 dollars) & 254,099 & 124,353 & 20,324 & $1,878,857$ \\
Distance to central business district (feet) & 35,874 & 18,590 & 5,387 & 109,487 \\
\hline
\end{tabular}

(2014 dollars). Of the 55,766 transaction pairs used in our analysis, 95 were brought inside the UGB between property sales, and 422 are in the 100-year floodplain.

\section{Restoration Data}

The location and characteristics of restoration projects in the study area are based, in part, on information from the Conservation Registry, ${ }^{9}$ a free online database. Projects in the Johnson Creek Watershed Restoration Project Census in the Conservation Registry had few analyzable variables, numerous duplicate entries, entries that included interventions other than restoration projects, and many projects with inaccurate or missing footprints. Therefore, existing records were checked against paper or digitized project plans, actions, reports, aerial photographs, and restoration managers' knowledge of restoration sites.

Restoration projects were identified using a definition used by the Pacific Coastal Salmon Recovery Fund (Jenkinson et al. 2006; Katz et al. 2007). Government agencies including the City of Portland Bureau of Environmental Services, Metro, Water Environment Services of Clackamas County, the City of Gresham, and Multnomah County Road Services were contacted for the most up-to-date restoration project maps and details. These were cross referenced with the Oregon Watershed Restoration Inventory, ${ }^{10}$ a database of restoration

\footnotetext{
${ }^{9}$ See The Conservation Registry, "Johnson Creek Watershed Restoration Project Census," available at http:// jcwc.conservationregistry.org/ (accessed June 4, 2016).

${ }^{10}$ See the Oregon Watershed Enhancement Board's Oregon Watershed Restoration Inventory, available at http:// oe.oregonexplorer.info/restorationtool/.
}

projects that are self-funded or funded by the Oregon Watershed Enhancement Board. ${ }^{11}$

A total of 209 restoration projects were undertaken in the study area from 1990 to 2014; Figure 2 shows the restoration projects in relation to the property sales used in our study. Projects varied from 0.008 to almost 140 ha ( 0.02 to $345.36 \mathrm{ac})$ and were categorized by one of five primary project goals: restoring floodplains, improving fish and wildlife habitat, mitigating storm water runoff, restoring wetlands, or removing invasive plants and revegetating with native plants. The Appendix includes a table with summary statistics for restoration projects included in our study.

The majority of projects, $73 \%$ by number and $70 \%$ by area, focused on removing invasive plants and revegetating with native plants. Project goals were classified by the authors using reported project actions and checked against the reported goals of the restoration agent. Many projects incorporated actions addressing more than one project goal, and for those cases the primary action was used as the primary project goal.

Figure 3 shows the number of restoration projects that started in a given year, categorized by primary project goal. Restoration projects began in the study area in 1990, with the earliest projects focused on restoring wetlands and creating and improving fish habitat. The period from 1995 to 2014 was dominated by projects that removed invasive plants and revegetated with native plants. Major floods

\footnotetext{
${ }^{11}$ Phone interview (2015) with Laura Guderyahn, Watershed Restoration Coordinator, City of Gresham, Oregon, about private landowner projects background; GIS map from the City of Gresham (2015); and GIS map of Johnson Creek watershed parks sites, 2009-2014, from Portland Parks and Recreation.
} 
Figure 3

Restoration Project Timeline

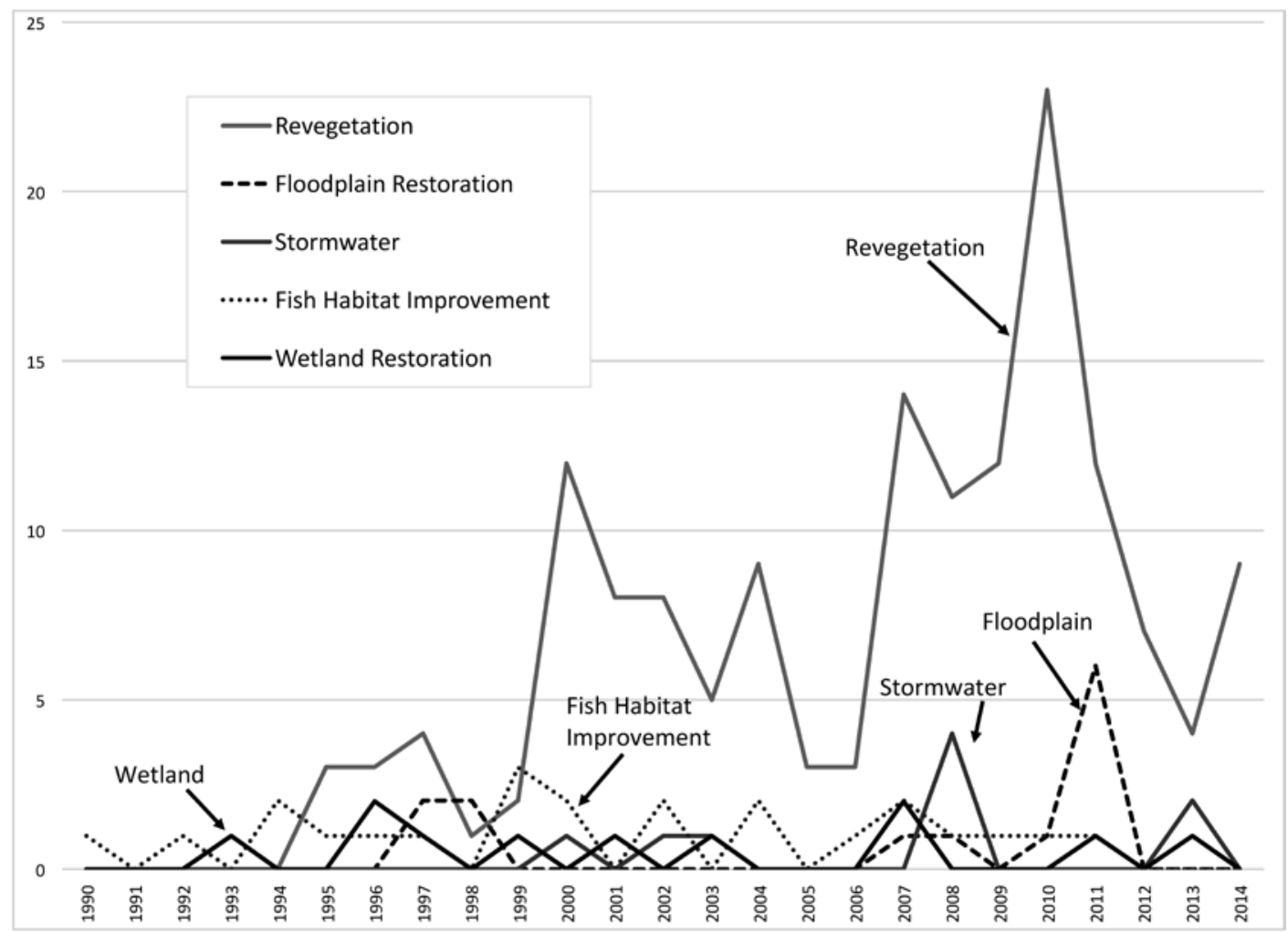

occurred in the study area in 1996 and 2009. ${ }^{12}$ Four floodplain restoration projects were started soon after the 1996 flood, and seven floodplain restoration projects were started in the five-year period after the 2009 flood.

Restoration occurs year-round, with different aspects of the work timed to minimize possible negative impacts to fish and wildlife, while ensuring maximum effectiveness. For example, in-stream work is done during midsummer to avoid impacts to adult salmon (present in spring and fall), while revegetation is done during the wet period from late fall to early spring to give new plantings the greatest chance of survival. ${ }^{13}$ Projects can include distinct and visually identifiable "footprints" that

\footnotetext{
${ }^{12}$ See USGS Oregon Water Science Center, "Top Ten Peaks of Johnson Creek since 1941," available at https:// or.water.usgs.gov/projs_dir/or175/.

${ }^{13}$ Phone interview with Noah Jenkins (2016), Riparian Program Manager, Johnson Creek Watershed Council.
}

were restored in different years. When this occurred, each footprint was coded separately to accurately reflect changes in restoration activities for that year. Projects with one footprint that occurred over multiple years were coded using the start date of the initial restoration.

Restoration projects were classified into four project phases to account for aesthetic and functional changes over time (Naiman 2013; Weisberg, Mortenson, and Dilts 2013). The first phase, the preproject phase, captures both the current state of the site and expectations about future project benefits ( 1 to 3 years before the project starts, referred to as age -3 to -1 years). The second phase, the project phase (age 0 to 2 years), is often characterized by noise, traffic disruptions, and poor aesthetics. Third is the postproject phase (age 3 to 5 years), when vegetation becomes established for projects that included plantings, and the fourth phase is the mature project phase (age 
Table 2

Transaction Pairs by Distance, Project Phase, and Project Type

\begin{tabular}{|c|c|c|c|c|c|}
\hline Variable & $\begin{array}{l}\text { Floodplain } \\
\text { Restoration }\end{array}$ & $\begin{array}{l}\text { Improve Fish and } \\
\text { Wildlife Habitat }\end{array}$ & $\begin{array}{l}\text { Mitigate Storm } \\
\text { Water Runoff }\end{array}$ & $\begin{array}{l}\text { Wetland } \\
\text { Restoration }\end{array}$ & $\begin{array}{l}\text { Remove Invasives } \\
\text { and Revegetate }\end{array}$ \\
\hline \multicolumn{6}{|l|}{0 to $0.25 \mathrm{~km}$ Distance } \\
\hline Preproject phase ( -3 to -1 years) & 128 & 218 & 43 & 123 & 1,052 \\
\hline Project phase (0 to 2 years) & 85 & 229 & 778 & 809 & 931 \\
\hline Postproject phase ( 3 to 5 years) & 64 & 242 & 33 & 134 & 815 \\
\hline Mature phase $(6+$ years $)$ & 54 & 285 & 27 & 161 & 753 \\
\hline \multicolumn{6}{|l|}{0.25 to $0.5 \mathrm{~km}$ Distance } \\
\hline Preproject phase & 289 & 658 & 103 & 308 & 2,280 \\
\hline Project phase & 204 & 726 & 1,830 & 1,952 & 2,074 \\
\hline Postproject phase & 145 & 711 & 93 & 310 & 1,770 \\
\hline Mature phase & 106 & 773 & 61 & 418 & 1,686 \\
\hline \multicolumn{6}{|l|}{0.5 to $1 \mathrm{~km}$ Distance } \\
\hline Preproject phase & 1,006 & 2,409 & 356 & 1,301 & 5,830 \\
\hline Project phase & 801 & 2,436 & 5,696 & 5,808 & 5,320 \\
\hline Postproject phase & 632 & 2,359 & 217 & 1,076 & 4,497 \\
\hline Mature phase & 511 & 2,241 & 134 & 1,443 & 4,145 \\
\hline
\end{tabular}

$6+$ years), when vegetation is firmly established.

Distance to a restoration project was measured from the nearest edge of the property to the nearest edge of the restoration project. Distance buffers of 0 to $0.25 \mathrm{~km}, 0.25$ to 0.5 $\mathrm{km}$, and 0.5 to $1 \mathrm{~km}$ were created, with projects in multiple buffers coded as being in each buffer. A project's age was calculated each time a property transacted and used to create 12 spatial-temporal variables. The number of transaction pairs by distance and project phase is summarized in the Appendix. Table 2 provides the number of transaction pairs in proximity to restoration projects by distance, project phase, and project type.

\section{Other Explanatory Variables}

The dist_CBD variable measures the Euclidean distance from the nearest edge of each property to the center of Portland's central business district. This variable is interacted with time variable dummies to explore whether the estimated effect from distance to the central business district has changed over time, perhaps due to increased development in the study area over time. $U G B$ was derived based on expansions of the UGB in the study area and the year a property transacted (RLIS Discovery 2016b). The Flood variable reflects properties located in the 100-year floodplain interacted with time variable dummies to capture temporal changes due to flooding events and changes in the federal National Flood Insurance Program (RLIS Discovery 2016a; Atreya, Ferreira, and Kriesel 2013; Kousky 2010).

\section{Methods}

The hedonic price method is widely used to estimate the marginal willingness to pay for environmental amenities and disamenities (Freeman, Herriges, and Kling 2014; Taylor 2017). Omitted variable bias is a concern because fully specified models must include detailed information about a property's location, structural, and environmental attributes. Alternative methods that reduce or eliminate omitted variables bias include difference-in-differences models, matching models (Ho et al. 2006), and repeat-sales models, which is the approach used in our study.

Repeat-sales models use data on the change in a property's sale price over time, so immutable attributes - such as a property's location and structural features-drop out of the equation. The change in a property's sale price is assumed to be associated with some type of "intervention" that occurred between 
sales, assuming all other factors are held constant. Some repeat sale studies have included location variables interacted with a time variable because a location's effect may not be stationary, so we incorporate distance to the central business district interacted with time into our models (Case et al. 2006; Kovacs et al. 2011).

Dynamic responses have been incorporated into repeat-sales models to explore how quickly property sale prices respond to the announcement of environmental contamination (Case et al. 2006) and efforts to restore an urban drain to a fully functioning wetland ecosystem (Polyakov et al. 2017). Time effects have been incorporated into hedonic models by estimating separate regressions for contaminated sites pre- and postannouncement of site remediation (Dale et al. 1999; Guignet 2014; Kiel 1995), using a dummy variable to indicate if a property was sold post-dam removal and restoration (Lewis, Bohlen, and Wilson 2008), and modeling changes in distance gradients pre- and postannouncement of hazardous waste sites (Ihlanfeldt and Taylor 2004).

Building on this research, we estimate repeat-sales models to explore the effect on a property's sale price from a restoration project's distance (Model 1), distance and project phase (Model 2), and distance, project phase, and project type (Model 3). Project outreach by government agencies and nonprofits is targeted at nearby property owners and neighborhood associations. Proximity also means that prospective buyers are more likely to notice these sites, so we expect, first, that properties that are closest to restoration sites ( 0 to 0.25 $\mathrm{km}$ buffer) are more likely than distant properties to experience changes in sale prices.

Second, we anticipate that effects will change based on a project's phase. With a few exceptions, such as the floodplain restoration projects, prospective buyers are unlikely to know that site restoration is about to begin, although buyers may notice if a site is in poor condition. The project phase is probably most noticeable to buyers, but the sign of this effect is uncertain and depends on a buyer's willingness to weigh the noise and disruption from a restoration project against a project's expected benefits once completed. We expect positive effects on property sale prices when the ecological and aesthetic benefits are realized, which may occur during the postproject and mature phases.

Third, we expect effects to vary by project type. Storm water mitigation and floodplain restoration projects provide benefits to nearby property owners because they reduce the risk of property damage; benefits to distant property owners exist but are likely minimal, for example, there may be fewer traffic disruptions if they travel through areas that had previously been flooded.

Projects that remove invasives and revegetate and projects that restore fish and wildlife habitat are likely to benefit nearby property owners to the extent that these projects improve aesthetics and are maintained over time. The benefit to property owners in other buffers $(0.25$ to $0.5 \mathrm{~km}$ and 0.5 to $1 \mathrm{~km})$, such as improvements in water quality and in the number and diversity of fish and wildlife, depends on the aggregate effect of many projects inside and outside of the study area, with some projects taking decades to achieve full functionality (Guillozet, Smith, and Guillozet 2014; Gardali and Holmes 2011).

Based on Kaza and BenDor's (2013) study, we expect restored wetlands to have negative effects on sale prices. However, if all restoration projects are perceived as "damaged goods," then we should expect negative effects for all project types. This negative effect, however, may be offset if there are tangible benefits, such as reduced flooding, directly linked to specific project types. This offsetting effect seems most likely for properties in the closest distance buffer.

\section{Repeat-Sales Equation}

A restoration project's effect is modeled using three different specifications. Model 1 includes a binary spatial variable $R_{\mathrm{S}}$ that equals 1 if a restoration project started between property sales within 0 to $0.25 \mathrm{~km}, 0.25$ to $0.5 \mathrm{~km}$, or 0.5 to $1 \mathrm{~km}$ of a property, and is 0 otherwise.

Letting $t^{0}$ represent the first transaction and $t^{\prime}$ the second transaction in a sale pair, and $P_{i}$ an individual property's sale price, Model 1 is represented by 


$$
\begin{aligned}
\ln \left(\frac{P_{i, t^{\prime}}}{P_{i, t^{0}}}\right)= & \beta_{0}+\sum_{t=2}^{T} \gamma_{t} d i s t_{-} C B D_{i} \times d_{t}+\sum_{S=1}^{3} \alpha_{S} R_{S} \\
& +\beta_{1} \text { Home_Age }_{i,\left(t^{\prime}, t^{0}\right)}+\beta_{2} U G B_{i} \\
& +\sum_{t=2}^{T} \phi_{t} \text { Flood }_{i} \times d_{t}+\sum_{t=2}^{T} \tau_{t} \times d_{t}+\varepsilon_{i,\left(t^{\prime}, t^{0}\right)},
\end{aligned}
$$

where $d_{t}=-1$ if $t=t^{0}, d_{t}=1$ if $t=t^{\prime}$, and $d_{t}=$ 0 if neither.

We include an intercept term, $\beta_{0}$, to capture nontemporal changes in house appreciation (Case et al. 2006). Location effects are captured using a property's distance from the city of Portland's central business district (dist_CBD $D_{i}$ ) interacted with $d_{t}$, which allows the effect of distance from central business district to vary over time (Case et al. 2006).

Controlling for a home's depreciation between sales has been cited as a concern in the literature (Case et al. 2006), so we included a home age variable (Home_Age $\left.e_{i,\left(t^{\prime}, t^{0}\right)}\right)$ using an approach described by Cohen et al. (2016) that calculates the percentage change in a home's age based on the time between sales $\left(t^{\prime}-t^{0}\right)$ and the home's initial age $\left(a_{i, t^{0}}\right)$ :

$$
\text { Home_Age } e_{i,\left(t^{\prime}, t^{0}\right)}=\ln \left(\frac{t^{\prime}-t^{0}}{a_{i, t^{0}}}\right) \text {. }
$$

Some properties were outside the Portland metropolitan area's UGB for the first transaction, but inside for the second transaction, so a binary term $\left(U G B_{i}\right)$ was included to estimate price changes that may result from changes in the development potential of these properties. The impact of being in the 100-year floodplain may change over time as a result of development increasing impervious surface area and, as a result, increasing discharges to Johnson Creek. Changes in government policies such as the terms and conditions for flood insurance may also change the effect of being in a 100-year floodplain. To capture these effects, a property's location in the 100-year floodplain $\left(\right.$ Flood $\left._{i}\right)$ was interacted with $d_{t}$.

The final set of terms $\tau_{t} \times d_{t}$ captures temporal changes in property sale prices in the study area; 1988 is the excluded year category. Error terms are correlated when a property transacts three or more times, so the model was esti- mated with generalized least squares using the approach described by Case et al. (2006).

Model 2 incorporates 12 spatial-temporal $\left(R_{S T}\right)$ binary variables to capture a property's distance from a restoration project ( 0 to 0.25 $\mathrm{km}$; 0.25 to $0.5 \mathrm{~km}$; 0.5 to $1 \mathrm{~km}$ ) and the project's age, which we categorize as a preproject phase $(-3$ to -1 years before the start of the project), project phase (0 to 2 years after the start of the project), postproject phase (3 to 5 years), or mature phase (6+ years). ${ }^{14}$ The number of transaction pairs for each distance/ phase category for this model is in the Appendix. This model specification is shown in equation [2].

$$
\begin{aligned}
\ln \left(\frac{P_{i, t^{\prime}}}{P_{i, t^{0}}}\right)= & \beta_{0}+\sum_{t=2}^{T} \gamma_{t} d i s t_{-} C B D_{i} \times d_{t} \\
& +\sum_{S T=1}^{12} \alpha_{S T}\left(R_{S T, t^{\prime}}-R_{\left.S T, t^{0}\right)}\right. \\
& +\beta_{1} \text { Home_Age }_{i,\left(t^{\prime}, t^{0}\right)}+\beta_{2} U G B_{i} \\
& +\sum_{t=2}^{T} \phi_{t} \text { Flood }_{i} \times d_{t}+\sum_{t=2}^{T} \tau_{t} \times d_{t}+\varepsilon_{i,\left(t^{\prime}, t^{0}\right)} .
\end{aligned}
$$

The third model (equation [3]) adds further complexity by modeling the five restoration project types (storm water, floodplain restoration, revegetation, wetland restoration, and fish and wildlife habitat), four project phases, and three distance buffers, for a total of 60 spatial-type-phase (STP) variables. Table 2 contains the number of transaction pairs in each distance/type/phase category for this model.

$$
\begin{aligned}
\ln \left(\frac{P_{i, t^{\prime}}}{P_{i, t^{0}}}\right)= & \beta_{0}+\sum_{t=2}^{T} \gamma_{t} d i s t_{-} C B D_{i} \times d_{t} \\
& +\sum_{S T P=1}^{60} \alpha_{S T P}\left(R_{S T P, t^{\prime}}-R_{S T P, t^{0}}\right) \\
& +\beta_{1} \text { Home_Age }_{i,\left(t^{\prime}, t^{0}\right)}+\beta_{2} U G B_{i} \\
& +\sum_{t=2}^{T} \phi_{t} \text { Flood }_{i} \times d_{t}+\sum_{t=2}^{T} \tau_{t} * d_{t}+\varepsilon_{i,\left(t^{\prime}, t^{0}\right)^{.}}
\end{aligned}
$$

\footnotetext{
${ }^{14}$ Let $S T=1$ for $R_{.25 \mathrm{~km} \text {,preproject }}, S T=2$ for $R_{.25 \mathrm{~km} \text {,project }}$, $S T=3$ for $R_{.25 \mathrm{~km} \text {,postproject }}, S T=4$ for $R_{.25 \mathrm{~km} \text {,mature }}, S T=5$ for $R_{.5 \mathrm{~km} \text {,preproject }}$, and so forth.
} 
Table 3

Models 1 and 2 Estimated Coefficients, Standard Errors in Parentheses

\begin{tabular}{|c|c|c|}
\hline Variable & Model 1: Distance & Model 2: Distance, Phase \\
\hline 0 to $0.25 \mathrm{~km}$ distance & $0.0020(0.0075)$ & \\
\hline Preproject phase ( -3 to -1 years) & & $-0.0014(0.0088)$ \\
\hline Project phase ( 0 to 2 years) & & $0.0182 * *(0.0093)$ \\
\hline Postproject phase ( 3 to 5 years) & & $0.0019(0.0095)$ \\
\hline Mature phase $(6+$ years $)$ & & $0.0114(0.0101)$ \\
\hline 0.25 to $0.5 \mathrm{~km}$ distance & $-0.0202 * * *(0.0055)$ & \\
\hline Preproject phase & & $-0.0020(0.0055)$ \\
\hline Project phase & & $-0.0048(0.0053)$ \\
\hline Postproject phase & & $-0.0071(0.0054)$ \\
\hline Mature phase & & $-0.0447 * * *(0.0075)$ \\
\hline 0.5 to $1 \mathrm{~km}$ distance & $-0.0184 * * *(0.0034)$ & \\
\hline Preproject phase & & $-0.0108 * * *(0.0038)$ \\
\hline Project phase & & $-0.0076 *(0.0040)$ \\
\hline Postproject phase & & $-0.0087 * *(0.0041)$ \\
\hline Mature phase & & $-0.0143 * * *(0.0047)$ \\
\hline Home_Age & $-0.0355 * * *(0.0011)$ & $-0.0308 * * *(0.0011)$ \\
\hline $\mathrm{UGB}^{-}$ & $0.1522 * * *(0.0202)$ & $0.1389 * * *(0.0197)$ \\
\hline$R^{2}$ & 0.5064 & 0.5008 \\
\hline Number of observations & 55,766 & 55,766 \\
\hline
\end{tabular}

$*, * *, * * *$ Significance at the $10 \%, 5 \%$, and $1 \%$ level, respectively.

\section{Results}

The results for Models 1 and 2 are presented in Table 3. The estimated effect on sale price if a restoration project is within 0 to $0.25 \mathrm{~km}$ of a property is positive but not significant in Model 1. Model 2, which focuses on a project's phase, finds a significantly positive effect of $1.84 \%$ for properties within 0 to $0.25 \mathrm{~km}$ of a project during the project phase ( 0 to 2 years old), which is when public outreach occurs and projects are most visible. Estimated effects are in comparison to properties that are not within $1 \mathrm{~km}$ of a restoration site.

Estimated coefficients for the 0.25 to 0.5 and 0.5 to $1 \mathrm{~km}$ distance buffers in Model 1 are significant with estimated effects of $-2 \%$ and $-1.82 \%$, respectively. In Model 2, projects in the mature phase within 0.25 to $0.5 \mathrm{~km}$ of a property are estimated to sell for $4.37 \%$ less. Estimated coefficients for projects in the 0.5 to $1 \mathrm{~km}$ buffer are all negative and significant for all project phases but the magnitudes are small. Estimated effects are $-1.07 \%$ for the preproject phase, $-0.76 \%$ for the project phase, $-0.87 \%$ for the postproject phase, and $-1.42 \%$ for the mature project phase.

The Home_Age variable is statistically significant in both models, implying that a $1 \%$ increase in a home's age between transactions is associated with a $3.49 \%$ decrease for Model 1 and a $3.03 \%$ decrease in a property's sale price for Model 2. The $U G B$ variable, which captures a property being brought inside the Portland metropolitan area's UGB between a property's first and second transaction shows an increase in sale price of $16.44 \%$ (Model 1) and $14.9 \%$ (Model 2).

Estimated coefficients on the temporal variables, which are not included in Table 3 , reflect an increase in property sale prices through 2008, a decline in sale prices due to the recession from 2009 through 2012, and the recovery in the last two years of the study period; the distance to the central business district by year coefficients are negative, as expected, with estimated magnitudes changing over time. A property's location in a flood zone is estimated to have a significantly negative effect for 10 of the 26 years in our study. The statistical and economic significance of these estimated coefficients reinforces the importance of including variables in a repeat sales model that may change in value over time (Case et al. 2006). ${ }^{15}$

Model 3 incorporates project type in addition to a project's phase and distance from a

\footnotetext{
${ }^{15}$ Full model results are available from the authors.
} 
Table 4

Model 3 Distance, Type, Phase Estimated Coefficients

\begin{tabular}{|c|c|c|c|c|}
\hline Variable & $\begin{array}{l}\text { Mitigate Storm } \\
\text { Water Runoff }\end{array}$ & $\begin{array}{l}\text { Floodplain } \\
\text { Restoration }\end{array}$ & $\begin{array}{l}\text { Remove Invasives } \\
\text { and Revegetate }\end{array}$ & $\begin{array}{l}\text { Wetland } \\
\text { Restoration }\end{array}$ \\
\hline \multicolumn{5}{|l|}{0 to $0.25 \mathrm{~km}$ Distance } \\
\hline $\begin{array}{l}\text { Preproject phase ( }-3 \text { to } \\
-1 \text { years) }\end{array}$ & $0.0651(0.0442)$ & $0.0361(0.0296)$ & $0.0104(0.0102)$ & $-0.0628 * *(0.0300)$ \\
\hline $\begin{array}{l}\text { Project phase ( } 0 \text { to } 2 \\
\text { years) }\end{array}$ & $0.0691 *(0.0362)$ & $-0.0508(0.0320)$ & $0.0131(0.0139)$ & $-0.0573 *(0.0348)$ \\
\hline $\begin{array}{l}\text { Postproject phase ( } 3 \text { to } \\
5 \text { years) }\end{array}$ & $-0.0032(0.0535)$ & $0.0122(0.0379)$ & $0.0209 *(0.0116)$ & $-0.0381(0.0303)$ \\
\hline Mature phase (6+ years) & $0.0330(0.0579)$ & $0.1025 * *(0.0471)$ & $0.0079(0.0123)$ & $-0.0698 * * *(0.0265)$ \\
\hline \multicolumn{5}{|l|}{0.25 to $0.5 \mathrm{~km}$ Distance } \\
\hline $\begin{array}{l}\text { Preproject phase } \\
\text { Project phase } \\
\text { Postproject phase } \\
\text { Mature phase }\end{array}$ & $\begin{array}{r}-0.0324(0.0280) \\
0.0156(0.0240) \\
0.0095(0.0289) \\
0.0095(0.0358)\end{array}$ & $\begin{array}{r}-0.0055(0.0196) \\
0.0101(0.0229) \\
-0.0081(0.0272) \\
-0.0369(0.0350)\end{array}$ & $\begin{array}{l}-0.0058(0.0068) \\
-0.0119(0.0091) \\
-0.0300 * * *(0.0080) \\
-0.0052(0.0085)\end{array}$ & $\begin{array}{l}-0.0319 *(0.0194) \\
-0.0082(0.0229) \\
-0.0540 * * *(0.0211) \\
-0.0556 * * *(0.0185)\end{array}$ \\
\hline \multicolumn{5}{|l|}{0.5 to $1 \mathrm{~km}$ Distance } \\
\hline $\begin{array}{l}\text { Preproject phase } \\
\text { Project phase } \\
\text { Postproject phase } \\
\text { Mature phase }\end{array}$ & $\begin{array}{c}-0.0443 * * *(0.0160) \\
-0.0107(0.0133) \\
0.0207(0.0205) \\
-0.0389 *(0.0237)\end{array}$ & $\begin{array}{l}-0.0402 * * *(0.0107) \\
-0.0260 * *(0.0115) \\
-0.0695 * * *(0.0133) \\
-0.0414 * * *(0.0159)\end{array}$ & $\begin{array}{l}-0.0160 * * *(0.0043) \\
0.0018(0.0056) \\
-0.0026 *(0.0051) \\
-0.0096(0.0056)\end{array}$ & $\begin{array}{l}-0.0204 * *(0.0096) \\
-0.0101(0.0128) \\
-0.0352 * * *(0.0117) \\
-0.0454 * * *(0.0108)\end{array}$ \\
\hline
\end{tabular}

property; results are presented in Table 4. Although not reported in Table 4, the estimated effects for the Home_Age and $U G B$ variables of $-3.41 \%$ and $15.74 \%$, respectively, are similar to estimated results in Models 1 and 2. Fish and wildlife habitat projects are only significant in the 0.5 to $1 \mathrm{~km}$ buffer for the mature project phase $(6+$ years $)$, with an estimated effect of $3.71 \% .^{16}$

Significantly positive effects are estimated for properties that are within 0 to $0.25 \mathrm{~km}$ of storm water, floodplain restoration, and revegetation projects, but the positive effects occur during different project phases. Storm water projects are estimated to have a significantly positive effect of $7.15 \%$ during the project phase, when public outreach about these projects is greatest and when they are most visible. Floodplain restoration projects are estimated to have a negative but not significant effect during the project phase, which is when noise and disruptions are greatest, and a significantly positive effect of $10.79 \%$ once a project reaches the mature phase $(6+$ years). Projects that remove invasives and revegetate,

\footnotetext{
${ }^{16}$ Full model results are available from the authors.
}

which have positive estimated coefficients for all project phases, are only significant with an estimated effect of $2.11 \%$ during the postproject phase (3 to 5 years), when vegetation is established but not overgrown. Protective barriers around newly planted vegetation, and signage at some sites, increase the visibility of revegetation projects in the postproject phase.

The estimated coefficients on wetlands within 0 to $0.25 \mathrm{~km}$ are all negative, with significant effects of $-6.09 \%$ for the preproject phase, $-5.57 \%$ for the project phase, and $-6.74 \%$ for the mature project phase.

Significantly negative results for the 0.25 to $0.5 \mathrm{~km}$ buffer include revegetation projects in the postproject phase and wetland restoration in the preproject, postproject, and mature phases. Significantly negative results are also found for the 0.5 to $1 \mathrm{~km}$ buffer for all restoration projects in the preproject phase. This may reflect the degraded state of sites selected for restoration. Overall, the properties located in the 0.5 to $1 \mathrm{~km}$ buffer experienced the greatest number of statistically significant negative effects of any buffer in our study. The likelihood of confounding events in this buffer that occur at the same time as 
the numerous restoration projects in our study is highly unlikely.

$F$-Tests show that Model 2 (distance, phase) is preferred to Model 1 (distance), $F_{9,55,673}=$ 5.40, and that Model 3 (distance, phase, type) is also preferred to Model 1, $F_{57,55,625}=1.40$. Model 3, however, is not preferred to Model $2, F_{48,55,625}=0.64$. Models 2 and 3 are preferred to Model 1, so our discussion focuses on those results.

\section{Discussion}

Private property owners, nonprofits, and government agencies have made significant investments in the study area to mitigate storm water runoff, restore floodplains, remove invasive plants, restore wetlands, and improve fish and wildlife habitat. Our first expectation, that properties closest to restoration sites are more likely than distant properties to experience changes in sale prices, is not supported by our models. This may be a result of two competing effects: a "damaged goods" effect (Kaza and BenDor 2013), which should depress property sale prices, and a "project benefit" effect, which should increase property sale prices. Our results can be explained by the benefit effect exceeding the damaged goods effect for some project phases and types in the 0 to $0.25 \mathrm{~km}$ buffer, these effects canceling each other out in the 0.25 to $0.5 \mathrm{~km}$ buffer, and the damaged goods effect dominating the benefit effect for the 0.5 to $1 \mathrm{~km}$ buffer. Estimated effects for wetland restoration projects are significantly negative for 9 of the 12 spatial-temporal variables, which can be explained by a dominant damaged goods effect.

Our second expectation is that estimated effects will change based on a project's phase. Our findings, that estimated coefficients differ by project phase, are consistent with dynamic price effects found in studies of changes in other environmental and natural resources. Cohen et al. (2016) find that sale prices decreased two years before declines in forest quality. Riddel (2001) and Case et al. (2006) determine that it took several years for changes in environmental quality to be fully capitalized into property sale prices. Polyakov et al. (2017) estimate that proximity to an urban drain restoration project initially depresses nearby property values before having a positive effect seven to eight years after project completion.

We also find, as expected, that estimated effects vary by project type. Properties in the 0 to $0.25 \mathrm{~km}$ buffer are estimated to experience a significantly positive effect for storm water, floodplain restoration, and revegetation projects during specific project phases. These positive effects occur when projects are most noticeable to prospective buyers: the project phase for storm water mitigation projects and the postproject phase for revegetation projects. Floodplain restoration projects have a large and significant effect in the mature phase, when "wetland, riparian, and upland plants are established, and trees mature but have yet to provide instream large wood habitat" (Bureau of Environmental Services 2012, 12).

Properties located within 0 to $0.25 \mathrm{~km}$ of a wetland restoration project are estimated to experience a change in property sale price of $-6.09 \%$ (preproject), $-5.57 \%$ (project), and $-6.74 \%$ (mature), while Kaza and BenDor (2013) estimate a change for properties within $0.125 \mathrm{mi}(0.2 \mathrm{~km})$ of restored aquatic sites of $-6 \%$, using the mean property sale price for their study area. Kaza and BenDor (2013) also estimate that properties within $0.25 \mathrm{mi}(0.4$ $\mathrm{km}$ ) of a restored aquatic site experience a change in sale price of $-4.14 \%$, while our estimates for wetland projects in the 0.25 to 0.5 $\mathrm{km}$ buffer are $-3.14 \%$ (preproject), $-5.26 \%$ (postproject), and $-5.41 \%$ (mature). The results of our study and Kaza and BenDor's (2013) are strikingly similar for the closest distance buffers, but Kaza and BenDor find positive effects for their $0.5 \mathrm{mi}(0.8 \mathrm{~km})$ and $0.75 \mathrm{mi}(1.2 \mathrm{~km})$ buffers, while estimated coefficients in our model are significantly negative for the 0.5 to $1 \mathrm{~km}$ buffer.

The hedonic price function may shift if buyer preferences change over time (Muehlenbachs, Spiller, and Timmins 2015), so our model incorporates a time-sensitive intercept and time-interacted hedonic attributes-distance to the city of Portland's central business district and if a property is located in the 100-year floodplain-to account for factors that may have shifted the hedonic price 
function along those dimensions. Expansions of the Portland metropolitan area's UGB are also incorporated into our analysis, because being inside the UGB may increase a property's development potential. The statistical and economic significance of these variables reinforces the need to include hedonic-type variables in repeat sales models. Our study area has experienced increases in population and home building, so a potential weakness of our modeling approach is that it does not capture changes in preferences for restoration projects, a home's age, or UGB expansions, because these variables were not interacted with a time variable due to degree-of-freedom constraints.

\section{Conclusion}

Urban streams have unique political and management issues. Urban streams often cross multiple jurisdictional boundaries, which increases the number of stakeholders, and development density means that more people are affected per stream mile. Legal requirements will also continue to shape restoration efforts, such as the National Marine Fisheries Service's Biological Opinion requiring stronger floodplain protection in Oregon and Washington (National Marine Fisheries Service 2016).

Our repeat-sales models estimate the effect of urban stream restoration projects on the sale price of nearby single-family residential properties, and whether estimated effects vary by project phase, distance, and type. Properties in closest proximity to storm water, floodplain, and revegetation projects experience a positive effect during different project phases, which we attribute to the "benefit effect" of these restoration projects exceeding a "damaged goods" effect. Estimated effects for wetland projects are significantly negative for 9 of the 12 distance/project phase variables, which we attribute to a dominant damaged goods effect. Our estimated effects are different from literature that estimate the effect of wetlands (Mahan, Polasky, and Adams 2000) and open spaces (Bolitzer and Netusil 2000; Acharya and Bennett 2001) on property sale prices, so using estimates from these studies, which focus on established sites, may not be appro- priate for benefit transfer (Lewis and Landry 2017).

Modeling the effects of urban stream restoration projects is challenging because of the extensive number of projects, diversity of project types, and the number of organizations involved in restoration efforts. Since we use a repeated sales model to guard against unobserved, time-invariant confounders, and multiple temporal interaction terms in the hedonic function to allow for time-varying price surface shifts and changes in preferences, we believe that our estimates are relatively robust to omitted variable problems. Perhaps a task for future research might be to explore if tastes for restoration sites have changed over time. This would have overly taxed the data underlying our study, which focused instead on types of restoration interventions as well as implementation phases, plus their interactions. Our analysis favors using models that include project distance and phase or project distance, phase, and type, but additional research should continue to explore the best way to capture a project's aesthetics, functionality, and area. Public outreach occurs primarily during the project phase and is focused on property owners closest to restoration projects. Future research should explore if public outreach efforts that extend further into the community, and continue throughout the postproject and mature project phases, can counteract the "damaged goods" effect associated with these projects.

Urban restoration projects improve regulating and supporting ecosystem services such as buffering of flood flows, maintenance of water quality, minimization of erosion, and maintenance of aquatic food webs (Pander and Geist 2013; Palmer, Filoso, and Fanelli 2014; Yeakley et al. 2016). However, full functionality may take decades for some restoration projects (Guillozet, Smith, and Guillozet 2014; Gardali and Holmes 2011); these changes may not be observed by private property owners, and benefits are diffuse (Hoang, Fenner, and Skenderian 2016).

Our research estimates effects on property sale prices from urban stream restoration projects that policy makers and stakeholders should consider when undertaking these projects. Our estimates, however, have limitations 
because they capture use values capitalized into property sale prices only for property owners in the study area. These projects may represent a Pareto improvement if nonuse values, and use values received by people outside of the proximate project area are includedan outcome found in several stated preference studies on stream restoration (Holmes et al. 2004; Kenney et al. 2012; Loomis et al. 2000; Loomis 2006). A complete accounting of use and nonuse values, and how those values change based on a project's phase, distance, and type, is necessary to guide sound decision-making about future investments in urban stream restoration projects.

\section{Acknowledgments}

This work was supported by the USDA National Institute of Food and Agricultural and Food Research Initiative Competitive Program, Agriculture Economics and Rural Communities, grant number 2014-05739, and the Carney Economics Fund at Reed College. We gratefully acknowledge assistance from Kristin Bott, Jed Cohen, Geof Donovan, Laura Guderyahn, Chester Ismay, Noah Jenkins, Robin Jenkinson, Joe Marquez, Daniel Newberry, Nigel Nicholson, Maggie Skenderian, Eric Watson, Marie Walkiewicz, Leslie White, participants in 2016 Association of Environmental and Resource Economists Sessions at the Western Economic Association Meeting in Portland, Oregon, and participants in the 2015 Urban Water and Flood Risk Management: The Blue-Green Advantage A China-UK-US Knowledge Exchange Workshop, University of Nottingham Ningbo Campus, China.

\section{References}

Acharya, Gayatri, and Lynne Lewis Bennett. 2001. "Valuing Open Space and Land-Use Patterns in Urban Watersheds." Journal of Real Estate Finance and Economics 22 (2-3): 221-37.

Ahilan, S., M. Guan, A. Sleigh, N. Wright, and H. Chang. 2018. "The Influence of Floodplain Restoration on Flow and Sediment Dynamics in an Urban River." Journal of Flood Risk Management 11 (S2): S986-S1001.

Atreya, Ajita, Susana Ferreira, and Warren Kriesel. 2013. "Forgetting the Flood? An Analysis of the Flood Risk Discount over Time." Land Economics 89 (4): 577-96.

Bergstrom, John C., and John B. Loomis. 2017. "Economic Valuation of River Restoration: An Analysis of the Valuation Literature and Its Uses in Decision-making." Water Resources and Economics 17 (January): 9-19.

Bernhardt, E. S., M. A. Palmer, J. D. Allan, G. Alexander, K. Barnas, S. Brooks, J. Carr, S. Clayton, C. Dahm, J. Follstad-Shah, et al. 2005. "Ecology: Synthesizing U.S. River Restoration Efforts.” Science 308 (5722): 636-37.

Bolitzer, B., and N. R. Netusil. 2000. "The Impact of Open Spaces on Property Values in Portland, Oregon." Journal of Environmental Management 59 (3): 185-93.

Bureau of Environmental Services. 2012. Johnson Creek Restoration Projects Effectiveness Monitoring: Reporting on Data Collected from 1997 through 2010. Portland, OR: City of Portland.

Case, Bradford, Peter F. Colwell, Chris Leishman, and Craig Watkins. 2006. "The Impact of Environmental Contamination on Condo Prices: A Hybrid Repeat-Sale/Hedonic Approach.” Real Estate Economics 34 (1): 77-107.

Che, Yue, Kai Yang, Enuo Wu, Zhaoyi Shang, and Weining Xiang. 2012. "Assessing the Health of an Urban Stream: A Case Study of Suzhou Creek in Shanghai, China." Environmental Monitoring and Assessment 184 (12): 7425-38.

Clackamas County Assessor. 2015. "Clackamas County Property Transactions 2012-2014."

Cohen, Jed, Christine E. Blinn, Kevin J. Boyle, Thomas P. Holmes, and Klaus Moeltner. 2016. "Hedonic Valuation with Translating Amenities: Mountain Pine Beetles and Host Trees in the Colorado Front Range." Environmental and Resource Economics 63 (3): 613-42.

Collins, Alan, Randy Rosenberger, and Jerald Fletcher. 2005. "The Economic Value of Stream Restoration." Water Resources Research 41 (2): W02017.

Dale, Larry, James C. Murdoch, Mark Thayer, and Paul A. Waddell. 1999. "Do Property Values Rebound from Environmental Stigmas? Evidence from Dallas." Land Economics 75 (2): 311-26.

Federal Emergency Management Agency (FEMA). 2006. Final Environmental Assessment: East Lents Floodplain Restoration Project. Washington, DC: U.S. Department of Homeland Security. Available at www.fema.gov/media-libr ary-data/20130726-1528-20490-0290/fema_ east_lents_east_lents_final_environmental_assessment_8_31_2006.pdf. 
Freeman, A. Myrick, Joseph A. Herriges, and Catherine L. Kling. 2014. The Measurement of Environmental and Resource Values: Theory and Methods. Third edition. New York: RFF Press.

Gardali, Thomas, and Aaron L. Holmes. 2011. "Maximizing Benefits from Riparian Revegetation Efforts: Local- and Landscape-Level Determinants of Avian Response." Environmental Management 48 (1): 28-37.

Guignet, Dennis. 2014. "To Sell or Not To Sell: The Impacts of Pollution on Home Transactions." NCEE Working Paper Series, 2014-1. Washington, DC: National Center for Environmental Economics.

Guillozet, Peter, Kendra Smith, and Kathleen Guillozet. 2014. "The Rapid Riparian Revegetation Approach." Ecological Restoration 32 (2): 113-24.

Ho, Daniel E., Kosuke Imai, Gary King, and Elizabeth A. Stuart. 2006. "Matching as Nonparametric Preprocessing for Reducing Model Dependence in Parametric Causal Inference." Political Analysis 15 (3): 199-236.

Hoang, L., R. A. Fenner, and M. Skenderian. 2016. "A Conceptual Approach for Evaluating the Multiple Benefits of Urban Flood Management Practices." Journal of Flood Risk Management September, doi:10.1111/jfr3.12267.

Holmes, Thomas P., John C. Bergstrom, Eric Huszar, Susan Kask, and Fritz Orr. 2004. "Contingent Valuation, Net Marginal Benefits, and the Scale of Riparian Ecosystem Restoration." Ecological Economics 49 (1): 19-30.

Hughes, Robert M., Susie Dunham, Kathleen G. Maas-Hebner, J. Alan Yeakley, Carl Schreck, Michael Harte, Nancy Molina, Clinton C. Shock, Victor W. Kaczynski, and Jeff Schaeffer. 2014. "A Review of Urban Water Body Challenges and Approaches: (1) Rehabilitation and Remediation.” Fisheries 39 (1): 18-29.

Ihlanfeldt, Keith R., and Laura O. Taylor. 2004. "Externality Effects of Small-Scale Hazardous Waste Sites: Evidence from Urban Commercial Property Markets." Journal of Environmental Economics and Management 47 (1): 117-39.

Jenkinson, Robin G., Katie A. Barnas, Jeffrey H. Braatne, Emily S. Bernhardt, Margaret A. Palmer, and J. David Allan. 2006. "Stream Restoration Databases and Case Studies: A Guide to Information Resources and Their Utility in Advancing the Science and Practice of Restoration.” Restoration Ecology 14 (2): 177-86.

Johnson Creek Watershed Council. 2003. Johnson Creek Watershed Action Plan: An Adaptive Ap- proach. Portland, OR: Johnson Creek Watershed Council.

Johnston, Robert J., Gisele Magnusson, Marisa J. Mazzotta, and James J. Opaluch. 2002. "Combining Economic and Ecological Indicators to Prioritize Salt Marsh Restoration Actions." American Journal of Agricultural Economics 84 (5): 1362-70.

Katz, Stephen L., Katie Barnas, Ryan Hicks, Jeff Cowen, and Robin Jenkinson. 2007. "Freshwater Habitat Restoration Actions in the Pacific Northwest: A Decade's Investment in Habitat Improvement." Restoration Ecology 15 (3): 494-505.

Kaza, Nikhil, and Todd K. BenDor. 2013. "The Land Value Impacts of Wetland Restoration." Journal of Environmental Management 127 (September): 289-99.

Kenney, Melissa A., Peter R. Wilcock, Benjamin F. Hobbs, Nicholas E. Flores, and Daniela C. Martínez. 2012. "Is Urban Stream Restoration Worth It?" Journal of the American Water Resources Association 49 (3): 603-15.

Kiel, Katherine A. 1995. "Measuring the Impact of the Discovery and Cleaning of Identified Hazardous Waste Sites on House Values." Land Economics 71 (4): 428-35.

Kline, Jeffrey D., Paul Thiers, Connie P. Ozawa, J. Alan Yeakley, and Sean N. Gordon. 2014. "How Well Has Land-Use Planning Worked under Different Governance Regimes? A Case Study in the Portland, OR-Vancouver, WA Metropolitan Area, USA." Landscape and Urban Planning 131 (November): 51-63.

Kousky, Carolyn. 2010. "Learning from Extreme Events: Risk Perceptions after the Flood." Land Economics 86 (3): 395-422.

Kovacs, Kent, Thomas P. Holmes, Jeffrey E. Englin, and Janice Alexander. 2011. "Dynamic Response of Housing Values to a Forest Invasive Disease: Evidence from a Sudden Oak Death Infestation." Environmental Resource Economics 49 (3): 445-71.

Lewis, Lynne Y., Curtis Bohlen, and Sarah Wilson. 2008. "Dams, Dam Removal, and River Restoration: A Hedonic Property Value Analysis." Contemporary Economic Policy 26 (2): 175-86.

Lewis, Lynne Y., and Craig E. Landry. 2017. "River Restoration and Hedonic Property Value Analyses: Guidance for Effective Benefit Transfer." Water Resources and Economics 17 (January): 20-31.

Loomis, John. 2006. "Importance of Including Use and Passive Use Values of River and Lake Res- 
toration." Journal of Contemporary Water Research and Education 134 (1): 4-8.

Loomis, John, Paula Kent, Liz Strange, Kurt Fausch, and Alan Covich. 2000. "Measuring the Total Economic Value of Restoring Ecosystem Services in an Impaired River Basin: Results from a Contingent Valuation Survey." Ecological Economics 33 (1): 103-17.

Lupi, Frank, Michael D. Kaplowitz, and John P. Hoehn. 2002. "The Economic Equivalency of Drained and Restored Wetlands in Michigan." American Journal of Agricultural Economics 84 (5): 1355-61.

Maas-Hebner, Kathleen G., Robert M. Hughes, and Carl B. Schreck. 2014. "Wild Salmonids in the Urban Environment: Lethal and Sublethal Effects." In Wild Salmonids in the Urbanizing Pacific Northwest, ed. J. Alan Yeakley, Kathleen G. Maas-Hebner, and Robert M. Hughes, 169-82. New York: Springer Science + Business Media.

Mahan, Brent L., Stephen Polasky, and Richard M. Adams. 2000. "Valuing Urban Wetlands: A Property Price Approach." Land Economics 76 (1): 100-13.

Merrick, Lesley, and Shannon Hubler. 2013. Oregon Water Quality Index Summary: Water Years 2002-2011 and 2003-2012. Hillsboro, OR: Oregon Department of Environmental Quality. Available at www.deq.state.or.us/lab/wqm/ docs/OWQISummary12.pdf.

Metro. 2014. "Regional Parks, Trails and Natural Areas Investments." Oregon Metro. Available at www.oregonmetro.gov/public-projects/nat ural-areas-bond-measures-and-levy (accessed August 13).

- 2016. "Parks and Nature Investments." Oregon Metro. Available at www.oregonmetro. gov/public-projects/parks-and-nature-invest ments (accessed June 7).

Metro Data Resource Center. 2014. "Portland Metropolitan Urban Growth Boundary Expansion History." Oregon Metro. Available at www. oregonmetro.gov/sites/default/files/2016/ 10/21/UGBhistory.pdf (updated; 2014 version no longer available).

— 2015. "Urban Growth Boundary Maps." Oregon Metro. Available at www.oregonmetro. gov/urban-growth-boundary.

Muehlenbachs, Lucija, Elisheba Spiller, and Christopher Timmins. 2015. "The Housing Market Impacts of Shale Gas Development." American Economic Review 105 (12): 3633-59.
Mueller, Julie M., Wes Swaffar, Erik A. Nielsen, Abraham E. Springer, and Sharon Masek Lopez. 2013. "Estimating the Value of Watershed Services Following Forest Restoration." Water Resources Research 49 (4): 1773-81.

Multnomah County Assessor. 2015. "Multnomah County Property Transactions 2012-2014."

Naiman, Robert. 2013. "Socio-ecological Complexity and the Restoration of River Ecosystems." Inland Waters 3 (4): 391-410.

National Marine Fisheries Service. 2016. Endangered Species Act (ESA) Section 7(a)(2) Jeopardy and Destruction or Adverse Modification of Critical Habitat Biological Opinion and Section 7(a)(2) "Not Likely to Adversely Affect" Determination for the Implementation of the National Flood Insurance Program in the State of Oregon. Report NWR-2011-3197. Seattle, WA: National Marine Fisheries Service, West Coast Region.

Njus, Elliot. 2017. "Seattle, Portland Lead in Rising Home Prices." The Oregonian, April 25, 2017. Available at www.oregonlive.com/front-porch/ index.ssf/2017/04/portland_seattle_lead_in_ risin.html.

NOAA Fisheries West Coast Region. 2012. Status of ESA Listings and Critical Habitat Designations for West Coast Salmon and Steelhead. Seattle, WA: NOAA Fisheries, West Coast Region. Available at www.westcoast.fisheries. noaa.gov/publications/gis_maps/maps/salmon_ steelhead/critical_habitat/wcr_salmonid_ch_ esa_july2016.pdf.

Ozawa, Connie P., ed. 2004. The Portland Edge. Washington, DC: Island Press.

Palmer, Margaret A., Solange Filoso, and Rosemary M. Fanelli. 2014. "From Ecosystems to Ecosystem Services: Stream Restoration as Ecological Engineering." Ecological Engineering 65 (April): 62-70.

Palmquist, Raymond B. 1982. "Measuring Environmental Effects on Property Values without Hedonic Regressions." Journal of Urban Economics 11 (3): 333-47.

Pander, Joachim, and Juergen Geist. 2013. "Ecological Indicators for Stream Restoration Success." Ecological Indicators 30 (July): 106-18.

Polyakov, Maksym, James Fogarty, Fan Zhang, Ram Pandit, and David J. Pannell. 2017. "The Value of Restoring Urban Drains to Living Streams." Water Resources and Economics 17 (January): 42-55.

Portland Bureau of Environmental Services. 2016. Watershed Overview. Portland: Portland Bu- 
reau of Environmental Services. Available at www.portlandoregon.gov/bes/article/318251 (accessed August 13, 2016).

Portland Parks and Recreation. 2014. Springwater Corridor. Portland: Portland Parks and Recreation. Available at www.portlandoregon. gov/parks/finder/index.cfm?action=ViewPark \&PropertyID=679 (accessed October 29, 2014).

Prakash, Mihir, Katerina Teksoz, Jessica Espey, Jeffrey Sachs, Michael Shank, and Guido Schmidt-Traub. 2017. The U.S. Cities Sustainable Development Goals Index 2017: Achieving a Sustainable Urban America. New York: Sustainable Development Solutions Network Secretariat of the United Nations.

Riddel, Mary. 2001. "A Dynamic Approach to Estimating Hedonic Prices for Environmental Goods: An Application to Open Space Purchase." Land Economics 77 (4): 494-512.

RLIS Discovery. 2016a. Flood Plains. Portland: Metro Regional Government. http://rlisdiscovery. oregonmetro.gov/?action=viewDetail\&layerID= 463 (accessed June 23, 2016).

RLIS Discovery. 2016b. UGB History. http://rlis discovery.oregonmetro.gov/?action=viewDe tail\&layerID=2508 (accessed June 23, 2016).

Schultz, Eric T., Robert J. Johnston, Kathleen Segerson, and Elena Y. Besedin. 2012. "Integrating Ecology and Economics for Restoration: Using Ecological Indicators in Valuation of Ecosystem Services.” Restoration Ecology 20 (3): 304-10.

Smith, Robert F., Robert J. Hawley, Martin W. Neale, Geoff J. Vietz, Erika Diaz-Pascacio, Jan Herrmann, Anthony C. Lovell, Chris Prescott, Blanca Rios-Touma, Benjamin Smith, and Ryan M. Utz. 2016. "Urban Stream Renovation: Incorporating Societal Objectives to Achieve Ecological Improvements." Freshwater Science 35 (1): 364-79.

Sonoda, Kazuhiro, J. Alan Yeakley, and Christopher E. Walker. 2001. "Near-Stream Landuse Effects on Streamwater Nutrient Distribution in an Urbanizing Watershed." JAWRA Journal of the American Water Resources Association 37 (6): 1517-32.

Streiner, Carol F., and John B. Loomis. 1995. "Estimating the Benefits of Urban Stream Restoration Using the Hedonic Price Method." Rivers 5 (4): 267-78.

Taylor, Laura O. 2017. "Hedonics." In A Primer on Nonmarket Valuation, ed. Patricia A. Champ, Kevin J. Boyle, and Thomas C. Brown, 235-92.
The Economics of Non-market Goods and Resources. Dordrecht: Springer.

U.S. Environmental Protection Agency (USEPA). 2013. Case Studies Analyzing the Economic Benefits of Low Impact Development and Green Infrastructure Programs. EPA 841-R-13-004. Washington, DC: U.S. Environmental Protection Agency.

- 2014. Green Infrastructure: Land Revitalization Success Stories. Washington, DC: U.S. Environmental Protection Agency.

U.S. Geological Survey. 2011. Effects of Urban Development on Stream Ecosystems in Nine Metropolitan Study Areas across the United States. Circular 1373. Reston, VA: U.S. Geological Survey.

Van Alphen, J. 2016. "The Delta Programme and Updated Flood Risk Management Policies in the Netherlands." Journal of Flood Risk Management 9 (4): 310-19.

Van Dyke, Erick S., and Adam J. Storch. 2009. Abundance and Distribution of Fish Species in City of Portland Streams. IGA 020-8038. Clackamas, OR: Oregon Department of Fish and Wildlife Ocean Salmon and Columbia River Program.

Weisberg, Peter J., Susan G. Mortenson, and Thomas E. Dilts. 2013. "Gallery Forest or Herbaceous Wetland? The Need for Multi-target Perspectives in Riparian Restoration Planning." Restoration Ecology 21 (1): 12-16.

Williams, John Sutherland, Karl K. Lee, and Daniel T. Snyder. 2010. Hydrology of Johnson Creek Basin: A Mixed-Use Drainage Basin in the Portland, Oregon, Metropolitan Area. Fact Sheet 2010-3030. Washington, DC: U.S. Geological Survey. Available at http://pubs.usgs. gov/fs/2010/3030/.

Yeakley, J. Alan, David E. Ervin, Heejun Chang, Elise F. Granek, Veronica Dujon, and Vivek Shandas. 2016. "Ecosystem Services of Streams and Rivers." In River Systems: Research and Management for the 21st Century, ed. David J. Gilvear, Malcolm T. Greenwood, Martin C. Thoms, and Paul J. Wood. Chichester, UK: John Wiley and Sons.

Yeakley, J. Alan, and Robert M. Hughes. 2014. "Global and Regional Context of Salmonids and Urban Areas." In Wild Salmonids in the Urbanizing Pacific Northwest, ed. J. Alan Yeakley, Kathleen G. Maas-Hebner, and Robert M. Hughes, 11-29. New York: Springer. 